\title{
Assessment of ethical behaviour on organizational performance
}

\author{
Henry Kiptum Yatich ${ }^{1 *}$ and Richard Musebe ${ }^{2}$ \\ ${ }^{1}$ Department of Management, School of Business and Economics, Mount Kenya University, Kenya. \\ ${ }^{2}$ Department of Development Studies, School of Human Resource Development, Moi University, Kenya.
}

Received 6 November 2016; Accepted 23 December, 2016

\begin{abstract}
Ethical behaviour if not practiced has the ability of reducing organization performance; it may cause disagreements, lawsuits, client dissatisfaction, poor service delivery, poor time management, and corruption among others. Some of the unethical behaviours observable that may affect organizational performance include arrogance, ignorance, neglect, absenteeism, alcohol consumption, smoking, and neglect among others. An organization's ability to bring forth ethical behaviour that goes above and beyond the call of duty can be a key asset and one that is difficult for competitors to imitate. The main objective of the study was to assess the influence of ethical behaviour on organizational performance in the Kenyan Public Health Sector. This was for the purpose of proposing appropriate strategies that could cultivate commitment and compliance among health workers in the sector. The study was based on the Social Learning Theory by Albert Bandura (1977). It posits that people learn from one another, by way of observation, imitation, and modeling. The study was carried out in Baringo District HospitalKabarnet, Rift-Valley Province. A mixed approach method was used with a survey research design. It applied a census inquiry on all the staff in the facility and 174 returned their questionnaires. Questionnaires were used for primary data collection. Data analysis was carried out using descriptive statistics and content analysis for ordinal and nominal data, respectively. Data presentation was done using tables, frequencies and percentages. The results showed that neglect, absenteeism, poor time management, corruption, disputes, and dishonest were rife in the sector. It was recommended that training of staff, government support and strict enforcement of the Public Officer Ethics Act (2003) be duly implemented to curb these vices. The office of the Ombudsman should put in place mechanisms that enable clients or patients to report any act of malpractice either via social media or text messages for prompt action.
\end{abstract}

Key words: Behaviour, ethics, performance, corruption.

\section{INTRODUCTION}

Behaviour is a function of both the persons and the environment (Lewin, 1943). Unethical behaviour by

employees can affect individuals, work teams, and even the organization (Andrews, 1989). Organizations thus

*Corresponding author. E-mail: yatich2002@gmail.com. Tel: +254-721303105.

Authors agree that this article remain permanently open access under the terms of the Creative Commons Attribution License 4.0 International License 
depend on individuals to act ethically (Wagel, 1987). Ethical behaviour is acting in ways that are consistent with one's personal values and the commonly held values of the organization and society (Naran, 1992). Unethical behaviour by employees can affect individuals, work teams, and even the organization (Andrews, 1989). Organizations thus depend on individuals to act ethically. An organization's ability to elicit ethical behaviour that goes above and beyond the call of duty can be a key asset and one that is difficult for competitors to imitate. 'It's not enough to just show up at 8 o'clock each morning and say, 'oh, I have done a wonderful thing" (Bolino et al., 2003).

Ethical behaviour in organizations is necessary because business can become unethical, and there are plenty of evidence as in today on unethical company practices. "Irrespective of the demands and pressures upon every organization, by virtue of its existence it is bound to be ethical, for at least two reasons: one, because whatever the business does affects its stakeholders and two, because every moment of action has paths of ethical as well as unethical paths wherein the existence of the business is justified by ethical alternatives it responsibly chooses" (Murphy, 2002).

According to Ackroydet al. (1999), there are various forms of unethical behaviour that are pervasive and costly problems when encountered by work organizations. Not surprisingly, there is a growing interest among organization scientists and practitioners in the patterns of and in the motivational factors affecting such behaviour, as well as in its consequences for both organizations and their members (Greenberg, 1997; Robinson and Bennett, 1995).

At times, we might ask: is it possible to look at peoples' attitudes, their state of mind? Can we influence the way they think about work? If we could change their attitudes, make them more positive, would they not behave differently? Ethical behaviour is important in all aspects of life because it is an essential part of the foundation on which a civilized society is established. "An organization or society that lacks ethical principles is bound to fail sooner or later" (Posters, 2003).

\section{The public health care delivery sector}

According to the research carried out by Kenya AntiCorruption Commission (KACC, 2010) in the health care delivery sector in February 2010, it identified the following forms of corruptions in the sector which are of ethical nature. There was fraudulent procurement of drugs and medical supplies whereby suppliers offer bribes to procuring entities in order to be awarded contracts unfairly. This caused overpricing and procurement of substandard goods and supplies. There existed outright theft of drugs and medical supplies by public officials responsible for their custody and administration. This resulted in shortage of drugs and supplies and consequent inability of citizens to access health care services. At times, patients are forced to give unofficial payments (bribes) to enable them access or speed up service delivery. This results in high cost of health care beyond the reach of ordinary citizens. There was use of public health facilities by health care workers to attend and treat their private patients. This was misuse of public facilities for private gain and creation of undue congestion. Theft and diversion of revenue collected at public health facilities by officers who are responsible for the administration of revenue at the health facilities. This caused shortage of drugs, medical supplies and other services at the health facilities. The health care insurance fraud was also cited where health workers and doctors inflated medical bills and prescribed unnecessary procedures and bills were to be paid through medical insurance schemes. This caused unwarranted increase in the cost of health care services. Absenteeism and conflict of interest by health care workers while attending to private or personal matters resulted in inability of patients to access quality health care services as and when required.

Kenya's Public Health Sector is akin to these practices of unethical nature. It is noted that previous studies have continued to report on the increase of unethical practices within the health sector. This is why the research endeavored to identify whether they still existed and what were the likely effects on organizational performance. The research carried out by KACC and TI tried to identify and expose unethical practices existing in the sector, but the study merely attempted to expose the probable effects of such practices and not the actual practices encountered by citizens.

\section{MATERIALS AND METHODS}

The study was carried out in Baringo District Hospital-Kabarnet, Rift-Valley Province. It is one of the 19 District Hospitals in Rift Valley Province. This is the largest hospital in the entire district. Kabarnet is the District Headquarters of Baringo, serving three constituencies. The facility boasts of not more than 182 employees, including nurses and health officers furthering their diploma studies at the adjacent Kenya Medical Training College.

\section{Research methodology and design}

The study was carried out in Baringo District Hospital-Kabarnet, Rift-Valley Province. It applied a census inquiry on all the staff in the facility and 174 returned their questionnaires. A census inquiry is a complete enumeration of all items in the 'population' (Kothari, 2004). It can be presumed that in such an inquiry, when all items are covered, no element of chance is left and the highest accuracy is obtained. How ever, in practice, this may not be true. How ever, it needs to be emphasized that $w$ hen the universe is a small one, it is no use resorting to a sample survey (Kothari, 2004). Primary data was collected using questionnaires, while secondary data was obtained from books, journals, previous research reports, government websites, organizational w ebsites and new spapers. 
Table 1. Unethical behaviours at the w orkplace (Primary Data).

\begin{tabular}{lcc}
\hline Unethical practices at the workplace & Frequency & Percent \\
\hline Disregard/ in-attendance & 8 & 34.8 \\
Lateness & 5 & 21.7 \\
Corruption & 4 & 17.4 \\
Conflict among staff & 2 & 8.7 \\
Drunkenness on duty & 1 & 4.3 \\
Dishonesty & 3 & 13.0 \\
Total & 23 & 100.0 \\
\hline
\end{tabular}

Analysis was carried out using descriptive statistics. These were presented using tables, frequencies and percentages.

\section{RESULTS AND DISCUSSION}

Ethical behaviours differ from one organization to the other, depending on the nature of their activities, though some may share some similarity. In the public health sector, they pay little attention to patient's plight (34.8\%) (Table 1).

It is not unusual in a public hospital to find a frustrated patient having waited for long hours, while others remain queuing, simply because the nurses did not notice whether the patient deserved emergency treatment or not. This attitude was evidenced when a patient died in Nyanza Provincial Hospital recently. "A patient who died unattended to after five hours at the Nyanza Provincial General Hospital was left lying on a bench for another three hours, the patient, claimed that medical staff on duty ignored them and kept them waiting unattended to for hours. "The nurse was arrogant. She said they were only dealing with emergency cases, which were not there at the time," she added. This brings out an element of neglect and dishonest (The Standard Newspaper, Tuesday, 7th July, 2009: 2). "I brought him to the hospital at $8 \mathrm{am}$ while walking in pain. He was not attended to until $11 \mathrm{pm}$ when he succumbed while lying on the bench". Posters (2003) recommended that ethical behaviour should be considered as an important pillar in all aspects of life because it is an essential part of the foundation on which a civilized society is established.

Nurses or hospital staffs frequently have gone on goslows or strikes accusing the hospital management and administrators of lack of accountability. The management on the other hand are known to accuse the striking staff of client neglect. Most staff report on duty as they like..." (The Sunday Nation, Sunday, 13th June, 2010: 21). All these issues remain a challenge in our Public Health Facilities today and much has to be done to curb such vices and ensure patient satisfaction, better use of scarce resources, and provision of drugs. Unethical behaviour negates any efforts towards improving organizational performance. With such occurences, such behaviours should not be encouraged at all cost since they can be costly to the organization and also to the clients it serves (Ackroyd et al., 1999).

Posters (2003) argue that such organizations are bound sooner or later. As such, the health sector in Kenya should not be allowed to exhibit such behaviours since it plays a pivotal role in health provision to the citizens of Kenya.

There was a strong indication that managing unethical behaviour has enormous contribution towards improving organizational performance. This is an indication that ethical behaviours should be practiced by employers and organizations that want to achieve customer satisfaction and promotes their organizational performance (Table 2). This finding agrees with Murphy (2002) who noted that ethical behaviour affects its stakeholders and that every moment of action has paths of ethical as well as unethical paths wherein the existence of the business is justified by ethical alternatives it responsibly chooses". It is worth noting that organization's employees are obligated to act ethically at all times so as to promote better organizational performance and its image (Wagel, 1987).

As highlighted by the management group, lack of enough resources and facilities by the hospital, lack of commitment by employees, are the most leading causes of unethical behaviour in the Health Sector. These factors are deterrent to the performance of duties effectively and efficiently (Table 3 ). Poor remuneration was also cited as a causative factor of unethical behaviour. This finding may attest to the KACC report, which stated that theft of drugs, absenteeism, unnecessary referrals, charging illegal fees and soliciting for bribes are main unethical forms of corruption in the Public Health Sector in Kenya, (Kenya Anti-Corruption Commission Report, 2010). This finding reveals that such behaviours by employees can affect individuals, work teams, and even the organization negatively (Andrews, 1989). 
Table 2. Frequency of the importance of addressing unethical behaviour w orkplace (Primary Data).

\begin{tabular}{lcc}
\hline Managing unethical behaviour increases organization performance & Frequency & Percent \\
\hline Yes & 149 & 98.7 \\
No & 2 & 1.3 \\
Total & 151 & 100.0 \\
\hline
\end{tabular}

Table 3. Frequency of causes of undesirable behaviour (Primary Data).

\begin{tabular}{lcc}
\hline Causes of undesirable behaviour & Frequency & Percent \\
\hline Lack or resources & 9 & 39.1 \\
lack of commitment & 7 & 30.4 \\
Poor remuneration & 5 & 21.7 \\
Stress & 2 & 8.7 \\
Total & 23 & 100.0 \\
\hline
\end{tabular}

Table 4. Frequency of benefits of ethical behaviour.

\begin{tabular}{lcc}
\hline Benefits of behaviour management & Frequency & Percent \\
\hline Better service delivery & 66 & 43.7 \\
Attainment of objectives & 31 & 20.5 \\
Harmony at work & 15 & 9.9 \\
Prudent resource use & 17 & 11.3 \\
Reduced conflict & 7 & 4.6 \\
United workforce & 15 & 9.9 \\
Total & 151 & 100.0 \\
\hline
\end{tabular}

\section{Benefits of behaviour management in organizations}

The fifth objective of the study was to establish the benefits accruing from ethical behaviour in organizations. To achieve this objective, respondents were asked to identify the benefits that accrue to the organization when ethical behaviour is put in place. The results were captured as shown in Table 4.

Better service delivery was cited by most respondents as the benefit accruing from behaviour management (43.7\%). This implies client satisfaction and improved organizational performance, (Table 4). All the managers agreed unanimously that behaviour management was essential and should be adapted to tame unethical practices.

\section{Conclusion}

Ethical behaviour among employees is crucial and imperative. From the research findings, there is a strong inclination that these vices are inherent in the public sector organizations. Transparency International (TI) in 2006 recognized embezzlement, theft, and corruption in procurement, corruption in payment systems as some practices existing in the health sector. This evidence shows the kind of problematic issue in this sector even in the 21st Century. Leadership in these firms should not be overlooked, since it provides a sense of direction to the junior staff. Failure to take action on errant employee shows other employees that there are no punishments to these vices, hence, the breeding of the said behaviours at the workplace. The study found that organizations do not have clear guidelines on how to punish or keep in check unethical behaviours. The Government of Kenya (2003) introduced the Public Officer Ethics Act (2003), which stipulates the ethical principles to be adhered to by all government employees as well as the resultant punishment to be meted on offenders. However, considering the ethical occurrences in the health sector, it can be argued that rarely do employees adhere to the act or that they may have not read the Act. When cases of theft of newborns, theft of government drugs, neglect of patients, and other unethical practices cases are reported the umbrella body does not act or is just slow in addressing the issues. In most cases the issues remain pending, forgotten or unresolved in unclear circumstance. 
Public scrutiny should be facilitated by transparent and democratic processes, oversight by the legislature and access to public information. Transparency should be further enhanced by measures such as disclosure systems and recognition of the role of an active and independent media in reporting unethical practices in the sector (Transparency International Report, 2006).

The Public Health Sector should facilitate an environment where high standards of conduct are encouraged by providing appropriate incentives for ethical behaviour, such as adequate working conditions and effective performance assessment. Managers have an important role in this regard by providing consistent leadership and serving as role models in terms of ethics and conduct in their professional relationship with political leaders, other public servants and citizens.

The Governance, Justice, Law and Order Sector (GJLOS) which is based under the office of the president should also intervene and investigate the issues concerning unethical practices in the Public Health Sector. In managing unethical behaviour, challenges are bound to emerge but through the law, conscience, accountability and responsibility, appropriate measures should be taken to contain undesirable unethical behaviours.

\section{RECOMMENDATIONS}

The study makes the following key recommendations:

(1) that the Public Officer Act (2003) which spells out the ethical requirements for all public sector employees is to be fully enforced and those found to have contravened the act be dealt with by the law. Employees should also have training sessions to discuss the Act and other relevant ethical principles.

(2) that the government through Governance, Justice, Law and Order office initiate the use of social media platform, and short text messaging services to enable patients and citizens report any form of misconduct as soon as possible for prompt action.
3) Finally, the Kenya Anti-Corruption Agency (KACC) should be roped into investigating any form of corrupt practices as soon as it is reported using the aforementioned communication channels.

Abbreviations: KMTC, Kenya Medical Training College; KACC, Kenya Anti-Corruption Commission; TI, Transparency International.

\section{Conflict of Interests}

The authors have not declared any conflict of interests.

\section{REFERENCES}

Ackroyd P, Thompson P (1999). Organizational Misbehavior. London: Sage.

Andrew s KR (1989). Ethics in practice. Harvard Business Review .

Bolino T, Bloodgood JM (2002). Citizenship Behaviour And The Creation Of Social Capital In Organizations. Academy of Management Review.

Government of Kenya (2003). Public Officer Ethics Act (2003. Retrieved from; w w w .kenyalaw .org

Greenberg J, Pyszczynski T, Solomon S, McGregor H,Harmon-Jones E, Simon L (1997). Terror management theory and self-esteem: Evidence that increased self-esteem reduces mortality salience effects. J. Pers. Soc. Psychol. 72(1):24-36.

KACC (2010). Kenya Anti-Corruption Commission (KACC) in the health care delivery sector in February 2010. Nairobi. KACC.

Kothari CR (2004). Research Methodology. Methods And Techniques. India: New age publisher.

Lew in K, Leeper RW (1943). Topological and Vector Psychology. University of Oregon.

Murphy PE (2002). Marketing Ethics at the Millennium.

Naran F (1992). Your Role in Shaping Ethics, Executive Excellence.

Posters (2003). Importance of Ethics in Business. San Diego: CA.

Robinson SL, Bennett RJ (1995). Development of a Measure of Workplace Deviance. J. Appl. Psychol. .Columbia. University of British Columbia.

Wagel WH (1987). A New Focus on Business Ethics at General Dynamics, Personnel. 